\title{
Supercritical water gasification of glycerol for Hydrogen production using response surface methodology
}

\author{
HOUCINAT Ibtissem, OUTILI Nawel*, MENIAI Abdesslam \\ Hassen \\ Chemical process faculty \\ LIPE, Constantine3 University \\ Constantine, Algeria \\ *nawel.outili@univ-constantine3.dz
}

\author{
WEISS-HORTALA Elsa \\ RAPSODEE Center \\ CNRS-UMR 5302, IMT Mines Albi \\ Albi, France
}

\begin{abstract}
Supercritical water gasification is a promising technology for the treatment of wet biomass and hydrogen. In this work, supercritical water gasification of glycerol was carried out in mini autoclaves to conduct a hydrogen production optimization study, using the central composite design of experiments. The effect of five operating conditions on the production of syngas by supercritical gasification has been studied namely, temperature $(400-600 \circ \mathrm{C})$, residence time (5min30s-124min30s), initial concentration of glycerol $(3,79-$ 25,21\% weight), pressure (20.21 MPa-29.76 MPa) and KOH catalyst quantity (0-2\% weight). The results revealed that a high temperature and a long residence time are desirable for hydrogen production and gasification efficiency, the temperature is the most positive effect on both responses, and the presence of potassium hydroxide as a catalyst has a considerable effect on hydrogen production. However, a long residence time is not necessary when handling at high temperature. Also, the increase in the initial glycerol concentration has a negative effect, while the pressure change has no significant effect. According to the models, a maximum of hydrogen produced and gasification efficiency are obtained when the operating conditions are temperature $=599.89 \circ \mathrm{C}$, residence time of $60.7957 \mathrm{~min}$, a pressure of 21.3 MPa for an initial glycerol concentration of 3.79 wt $\%$ and in the presence of 0.102 wt $\% \mathrm{KOH}$.
\end{abstract}

Keywords- supercritical water gasification; glycerol; $\mathrm{H}_{2}$ production; gasification efficiency

\section{INTRODUCTION}

Hydrogen is a clean and renewable energy vector [1], it is the cleanest fuel with zero carbon emission [2], its combustion leads only to the production of water $\mathrm{H}_{2} \mathrm{O}$ [3]. Hydrogen is often used for the treatment of heavy crude oil, the production of hydrocarbons from the hydrogenation process, the valorization of bio-oils, the manufacture of ammonia and methanol by chemical synthesis [4].
Due to the depletion of fossil energy, biomass as a source of renewable and environmentally friendly energy is a feedstock of hydrogen production [5], by biochemical or thermo chemical conversion [6], the production of hydrogen biochemically is sufficient for practical application, while thermo chemical conversion allows high hydrogen production with better energy efficiency [7]. Thermo chemical methods of hydrogen production are: pyrolysis, conventional gasification, and supercritical water gasification. Pyrolysis is a process of decomposition of carbonaceous materials, by the action of heat (up to $1000{ }^{\circ} \mathrm{C}$ ) in the absence of oxygen producing a solid (charcoal), condensable vapors (organic oils and water) and combustible permanent gases $\left(\mathrm{CO}, \mathrm{H}_{2}, \mathrm{CH}_{4}\right.$ and other light hydrocarbons $\mathrm{C} 2-\mathrm{C} 3)$ and incombustible $\left(\mathrm{CO}_{2}\right)$ [8]. Conventional gasification aims at the conversion of an organic charge into combustible gas, the reaction product is therefore a combustible gas $\left(\mathrm{CO}, \mathrm{H}_{2}, \mathrm{CH}_{4}, \mathrm{H}_{2} \mathrm{O}, \mathrm{N}_{2}\right)$ generated at high temperature $\left(800\right.$ to $\left.900{ }^{\circ} \mathrm{C}\right)$, under pressure or not, and an inert residue [9]. In the case of wet biomass, these processes are difficult to handle and have low energy efficiency [10]. To solve this problem, a process using the properties of water has been started, this process is supercritical water gasification,

which consists of carrying a wet biomass under conditions above the critical temperature and pressure of water (Tc $\geq 374{ }^{\circ} \mathrm{C}, \quad \mathrm{Pc} \geq 22.1 \mathrm{MPa}$ ), thus producing a mixture of recoverable gases composed mainly of $\left(\mathrm{H}_{2}, \mathrm{CH}_{4}, \mathrm{CO}_{2}, \mathrm{CO}\right.$ and some light hydrocarbons) [11]. This process doesn't require a drying step which makes it less expensive compared to conventional gasification and pyrolysis [12]. In addition, supercritical water gasification of biomass has a high hydrogen yield with sufficient pressure for storage and transport [13].

Therefore, gasification in supercritical water treated different real biomasses such as fruit pulp [14], wheat straw [15], sawdust [7], sugar cane bagasse [16] and olive oil waste [17]. Also, it was applied for model biomass such as cellulose [7], 
glucose [18], lignin [19], and glycerol [20], in tubular reactors $[15,21]$, or batch reactors $[16,22]$.

The literature on experimental studies shows a variety of operating parameters whose effect has been tested on the rate of hydrogen production such as temperature [20], initial concentration [22, 23], residence time [24] and pressure[22], as well as the presence of catalyst [25].

In order to control the selectivity of hydrogen production, an assembly of operating conditions and the presence of alkaline catalyst is essential. For this fact, an optimization study is required and many researchers have used the surface response methodology as an optimization tool.

The response surface methodology (RSM) using central composite design (CCD) was investigated on the hydrothermal gasification of lignin for the first time by K. Kang et al. [26], in a batch reactor, whose main objective was the optimization of the hydrogen yield by the effect of three parameters, the temperature, the pressure and the water / biomass ratio. A.Raheem et al. [27] have studied the influence of temperature, $\mathrm{ZnO}-\mathrm{Ni}-\mathrm{CaO}$ catalyst load and residence time for the hydrothermal gasification of algae studying several design responses (fractions of $\mathrm{H}_{2}, \mathrm{CO}, \mathrm{CO}_{2}$ and $\mathrm{CH}_{4}$ ).

However, in the last few years there has been a growing interest in glycerol as a biomass source of renewable energy, because of its growing generation, and availability at low cost, as a byproduct of biodiesel production by transesterification of vegetable oils[28, 29]. For these reasons, and in order to produce hydrogen, several researchers have studied gasification in supercritical water glycerol experimentally [2024], but very few researchers have carried out optimization studies on this biomass. From our bibliographic research only F.Yan et al. [30] studied the supercritical water gasification of crude glycerol, using the central composite experimental design to optimize hydrogen production from crude glycerol, and to study the effect of glycerol concentration, temperature and $\mathrm{KOH}$ concentration.

So, usually, optimization studies of supercritical gasification considered three parameters in their used experimental design. The present work focuses on a modeling study of the glycerol supercritical water gasification process, and the influence of five operating parameters, temperature, residence time, pressure, initial concentration and presence of potassium hydroxide as catalyst, on hydrogen production, using a central composite design, leading to quadratic correlations between the response and the studied factors.

\section{MATERIALS AND METHODS}

\section{A. Reagents}

The glycerol $\left(\mathrm{C}_{3} \mathrm{H}_{8} \mathrm{O}_{3}\right)$ used in this study was purchased from SIGMA ALDRICH, with a purity of $99.9 \%$ and glycerol solutions were prepared with ultrapure water. The experiments were conducted with solutions containing pure glycerol of concentrations in the range $[3,8-25,21 \%$ weight], in the presence of an alkaline catalyst, potassium hydroxide $\mathrm{KOH}$ with concentrations in the range [ $0-2 \%$ weight].

\section{B. Experimental protocol}

The experiments were carried out in the RAPSODEE laboratory of IMT- Mines of Albi in France, in mini autoclaves of internal volume of $5 \mathrm{ml}$. The volume of glycerol solutions were calculated using the density $(\rho)$ depending on the desired temperature and pressure conditions. This solution was introduced to the reactors with the appropriate quantity of potassium hydroxide as catalyst.

The reactor was in stainless steel 316, with inner and outer diameters of 8.5 and $31.4 \mathrm{~mm}$, respectively. The copper seal ensured tightness between the two parts of the autoclave [31]. When the solution was introduced into the reactor, and after closure, the reactor was installed in the oven (Nabertherm L5 / 11 / P320) previously heated to the desired temperature. A time of 9 minutes was necessary to the oven to achieve the desired temperature. Once the residence time of the reaction was reached, the reactor was installed under a hood for 20 minutes to be cooled to ambient temperature. Once the reactor was open, the manometer measured the overpressure (used to calculate the volume of total gas produced). Then, the gaseous and liquid phases were recovered and analyzed.

The recovered gases were analyzed by gaseous micro chromatography (Agilent PGC-3000), identifying and quantifying in few seconds the produced gases: $\mathrm{H}_{2}, \mathrm{CO}, \mathrm{CO}_{2}$, $\mathrm{CH}_{4}, \mathrm{C}_{2} \mathrm{H}_{4}, \mathrm{C}_{2} \mathrm{H}_{6}, \mathrm{C}_{3} \mathrm{H}_{8}$ and $\mathrm{C}_{4} \mathrm{H}_{10}$. Gas yield was defined as concentration of gas divided by initial concentration of glycerol.

\section{Design of experiments}

The central composite design was chosen because of its efficient estimation of the quadratic terms in the second degree model, by studying the effect of 5 operating parameters Temperature (T), residence time (ts), initial glycerol concentration $(\mathrm{Ci})$, pressure $(\mathrm{P})$, and potassium hydroxide as catalyst (Cat), with five levels for each factor as presented in table1. The studied responses of the design were: hydrogen production, gasification efficiency and gas yield. 52 experiments were carried out as suggested by the used CCD. The real factors variation according to the experiments as well as the experimental responses measurements are shown in tables I and II.

The $\mathrm{H}_{2}$ yield is calculated as follows:

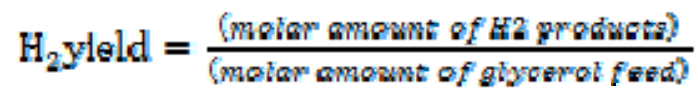


TABLEI. INTERVALS OF VARIATION OF THE STUDIED REAL-CODED FACTORS.

\begin{tabular}{|c|c|c|c|c|c|c|c|}
\hline \multirow{2}{*}{ Variable } & \multirow{2}{*}{ Units } & \multirow{2}{*}{ Symbols } & \multicolumn{5}{|c|}{ Ranges and Levels } \\
\cline { 4 - 8 } & & & - & -1 & 0 & +1 & $+2,38$ \\
\hline Temperature & ${ }^{\circ} \mathrm{C}$ & $\mathrm{T}$ & 400 & 458 & 500 & 542 & 600 \\
\hline $\begin{array}{c}\text { Residence } \\
\text { time }\end{array}$ & $\mathrm{min}$ & $\mathrm{ts}$ & 5.5 & 40 & 65 & 90 & 124.5 \\
\hline $\begin{array}{c}\text { Glycerol } \\
\text { concentration }\end{array}$ & $\begin{array}{c}\mathrm{Wt} \\
\%\end{array}$ & $\mathrm{Ci}$ & 3.8 & 10 & 14.5 & 19 & 25.21 \\
\hline $\begin{array}{c}\text { Pressure } \\
\mathrm{MPa}\end{array}$ & $\mathrm{P}$ & 20.2 & 23 & 25 & 27 & 29,76 \\
\hline $\begin{array}{c}\text { Potassium } \\
\text { hydroxide } \\
\text { catalyst } \\
\text { (KOH) }\end{array}$ & $\mathrm{Wt} \%$ & $\mathrm{Cat}$ & 0 & 0.6 & 1.0375 & 1.475 & 2.078 \\
\hline
\end{tabular}

In order to determine the optimal condition for a target objective, the $\mathrm{H}_{2}$ yield is related to the responses using a second order models expressed as follows:

$$
Y=\beta_{0}+\sum_{i=1}^{3} \beta_{i} x_{i}+\sum_{i=1}^{3} \beta_{\mathrm{ii}} x_{i}^{2}+\sum_{i=1}^{2} \sum_{j=i+1}^{3} \beta_{i j} x_{i} x_{j}
$$

Where $\mathrm{Y}$ is the studied response, $\mathrm{a}_{\mathrm{i}}$ are the model coefficients and $x_{i}$ the $i$ factor

\section{RESULTS AND DISCUSSIONS}

First we carried out the 52 experiments as presented in table 2 and the ai models coefficients are estimated for each studied response, using Minitab16 for data treatment of CDD experimental design.

The experimental results of the $\mathrm{H}_{2}$ yield are shown in Table II:

TABLEII. CENTRAL COMPOSITE MATRIX DESIGN WITH REAL VALUES OF FACTORS AND EXPERIMENTAL $\mathrm{H}_{2}$ YIELD.

\begin{tabular}{|l|l|l|l|l|l|l|}
\hline Run & T & ts & Ci & P & Cat & $\begin{array}{c}\mathbf{Y}_{\mathbf{H} 2} \\
\text { (experimental) }\end{array}$ \\
\hline 1 & 458 & 40 & 10 & 23 & 0,6 & 0,40060 \\
\hline 2 & 542 & 40 & 10 & 23 & 0,6 & 0,65959 \\
\hline 3 & 458 & 90 & 10 & 23 & 0,6 & 0,57200 \\
\hline 4 & 542 & 90 & 10 & 23 & 0,6 & $\mathbf{0 , 6 7 4 9 2}$ \\
\hline 5 & 458 & 40 & 19 & 23 & 0,6 & 0,29346 \\
\hline 6 & 542 & 40 & 19 & 23 & 0,6 & 0,47693 \\
\hline 7 & 458 & 90 & 19 & 23 & 0,6 & 0,25373 \\
\hline 8 & 542 & 90 & 19 & 23 & 0,6 & 0,45387 \\
\hline 9 & 458 & 40 & 10 & 27 & 0,6 & 0,22064 \\
\hline 10 & 542 & 40 & 10 & 27 & 0,6 & 0,66533 \\
\hline 11 & 458 & 90 & 10 & 27 & 0,6 & 0,53968 \\
\hline 12 & 542 & 90 & 10 & 27 & 0,6 & 0,53005 \\
\hline 13 & 458 & 40 & 19 & 27 & 0,6 & 0,14161 \\
\hline 14 & 542 & 40 & 19 & 27 & 0,6 & 0,42988 \\
\hline 15 & 458 & 90 & 19 & 27 & 0,6 & 0,31280 \\
\hline 16 & 542 & 90 & 19 & 27 & 0,6 & 0,45814 \\
\hline 17 & 458 & 40 & 10 & 23 & 1,475 & 0,52780 \\
\hline 18 & 542 & 40 & 10 & 23 & 1,475 & 0,71939 \\
\hline 19 & 458 & 90 & 10 & 23 & 1,475 & 0,50800 \\
\hline 20 & 542 & 90 & 10 & 23 & 1,475 & 0,60490 \\
\hline 21 & 458 & 40 & 19 & 23 & 1,475 & 0,30548 \\
\hline 22 & 542 & 40 & 19 & 23 & 1,475 & 0,52000 \\
\hline & & & & & & \\
\hline
\end{tabular}

\begin{tabular}{|l|l|l|l|l|l|l|}
\hline 23 & 458 & 90 & 19 & 23 & 1,475 & 0,36633 \\
\hline 24 & 542 & 90 & 19 & 23 & 1,475 & 0,49413 \\
\hline 25 & 458 & 40 & 10 & 27 & 1,475 & 0,48838 \\
\hline 26 & 542 & 40 & 10 & 27 & 1,475 & 0,82298 \\
\hline 27 & 458 & 90 & 10 & 27 & 1,475 & 0,68719 \\
\hline 28 & 542 & 90 & 10 & 27 & 1,475 & 0,64337 \\
\hline 29 & 458 & 40 & 19 & 27 & 1,475 & 0,24939 \\
\hline 30 & 542 & 40 & 19 & 27 & 1,475 & 0,53612 \\
\hline 31 & 458 & 90 & 19 & 27 & 1,475 & 0,48735 \\
\hline 32 & 542 & 90 & 19 & 27 & 1,475 & 0,46723 \\
\hline 33 & 400,107 & 65 & 14,5 & 25 & 1,0375 & 0,29718 \\
\hline 34 & 599,893 & 65 & 14,5 & 25 & 1,0375 & 0,58585 \\
\hline 35 & 500 & 5,54 & 14,5 & 25 & 1,0375 & 0,12527 \\
\hline 36 & 500 & 124,46 & 14,5 & 25 & 1,0375 & 0,51314 \\
\hline 37 & 500 & 65 & 3,7971 & 25 & 1,0375 & 1,29991 \\
\hline 38 & 500 & 65 & 25,2029 & 25 & 1,0375 & 0,41237 \\
\hline 39 & 500 & 65 & 14,5 & 20,2432 & 1,0375 & 0,16676 \\
\hline 40 & 500 & 65 & 14,5 & 29,7568 & 1,0375 & 0,32425 \\
\hline 41 & 500 & 65 & 14,5 & 25 & 0 & 0,42929 \\
\hline 42 & 500 & 65 & 14,5 & 25 & 2,07806 & 0,70090 \\
\hline 43 & 500 & 65 & 14,5 & 25 & 1,0375 & 0,34295 \\
\hline 44 & 500 & 65 & 14,5 & 25 & 1,0375 & 0,38951 \\
\hline 45 & 500 & 65 & 14,5 & 25 & 1,0375 & 0,31733 \\
\hline 46 & 500 & 65 & 14,5 & 25 & 1,0375 & 0,36428 \\
\hline 47 & 500 & 65 & 14,5 & 25 & 1,0375 & 0,37327 \\
\hline 48 & 500 & 65 & 14,5 & 25 & 1,0375 & 0,38562 \\
\hline 49 & 500 & 65 & 14,5 & 25 & 1,0375 & 0,39709 \\
\hline 50 & 500 & 65 & 14,5 & 25 & 1,0375 & 0,36428 \\
\hline 51 & 500 & 65 & 14,5 & 25 & 1,0375 & 0,31733 \\
\hline 52 & 500 & 65 & 14,5 & 25 & 1,0375 & 0,37327 \\
\hline & & & & & & \\
\hline
\end{tabular}

\section{A. Models}

The complete quadratic model of the second degree describing the hydrogen production according to the operating parameters (in real value) is as follows:

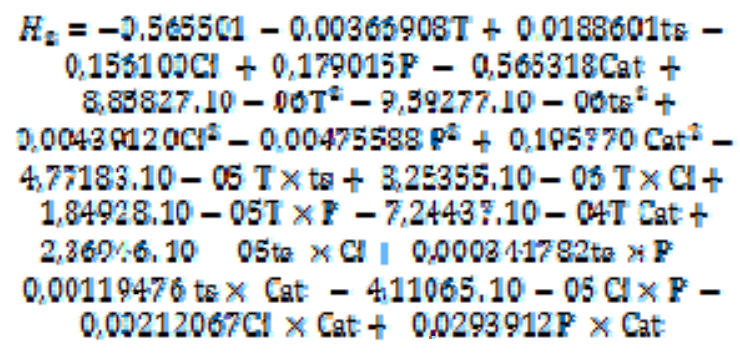

The coefficients of determination $\left(\mathrm{R}^{2}\right)$ of the mathematical models describing hydrogen production is 0.896 . Table III presents the regression coefficients and the significance tests for all the parameters studied and their interactions with a statistical risk of $5 \%$.

TABLEIII. REGRESSION COEFFICIENTS AND SIGNIFICATION TESTS FOR HYDROGEN PRODUCTION AND GASIFICATION EFFICIENCY.

\begin{tabular}{|l|c|c|c|}
\hline \multirow{2}{*}{ Source } & \multicolumn{3}{|c|}{$\mathbf{H}_{2}$} \\
\cline { 2 - 4 } & Coef & t & P \\
\hline Constant & 0,363912 & 14,390 & 0 \\
\hline $\mathrm{T}$ & 0,080551 & 6,588 & 0 \\
\hline $\mathrm{Ts}$ & 0,035061 & 2,868 & 0,007 \\
\hline $\mathrm{Ci}$ & - & $-9,686$ & 0 \\
\hline
\end{tabular}




\begin{tabular}{|c|c|c|c|}
\hline & 0,118422 & & \\
\hline $\mathrm{P}$ & 0,005162 & 0,422 & 0,676 \\
\hline Cat & 0,045963 & 3,759 & 0,001 \\
\hline $\mathrm{T}^{2}$ & 0,015626 & 1,486 & 0,147 \\
\hline $\mathrm{Ts}^{2}$ & $\begin{array}{c}- \\
0,005995\end{array}$ & $-0,570$ & 0,573 \\
\hline $\mathrm{Ci}^{2}$ & 0,088922 & 8,454 & 0 \\
\hline $\mathrm{P}^{2}$ & $\begin{array}{c}- \\
0,019024\end{array}$ & $-1,809$ & 0,080 \\
\hline Cat $^{2}$ & 0,037472 & 3,563 & 0,001 \\
\hline $\mathrm{T}$ ts & $\begin{array}{c}- \\
0,050104\end{array}$ & $-3,522$ & 0,001 \\
\hline $\mathrm{TCi}$ & 0,001560 & 0,110 & 0,913 \\
\hline $\mathrm{TP}$ & 0,001553 & 0,109 & 0,914 \\
\hline TCat & $\begin{array}{c}- \\
0,013312\end{array}$ & $-0,936$ & 0,357 \\
\hline Ts Ci & 0,002666 & 0,187 & 0,853 \\
\hline Ts $P$ & 0,017089 & 1,201 & 0,239 \\
\hline Ts Cat & $\begin{array}{c}- \\
0,013068\end{array}$ & $-0,919$ & 0,365 \\
\hline Ci P & $\begin{array}{c}- \\
0,000370\end{array}$ & $-0,026$ & 0,979 \\
\hline Ci Cat & $\begin{array}{c}- \\
0,004175\end{array}$ & $-0,294$ & 0,771 \\
\hline P Cat & 0,025717 & 1,808 & 0,080 \\
\hline
\end{tabular}

Coef $=$ regression coefficients of the model, $t$-value $=$ Student test value, $P$-value $=$ probability value

According to Table III, all the main factors have a significant effect on the production of hydrogen except the pressure ( $p$-value $>0.050$ ). As reported in $[32,33]$, a strong pressure is in favor of the water gas-shift reaction, methanation of the $\mathrm{CO}$ and $\mathrm{CO}_{2}$, but reduces the rate of decomposition reaction of the biomass by radical reaction. This explains why the pressure has no significant effect on hydrogen production and gasification efficiency.

The initial concentration of glycerol has the most significant but negative effect $t=-9.686, p$-value $=0$ and $t=-$ 3.451 , $\mathrm{p}$-value $=0.002$, respectively, an increase in the initial concentration causes a decrease in the hydrogen produced. If we compare experiments 37 and 38 , when initial concentration of glycerol rises from $3.79 \mathrm{wt} \%$ to $25.21 \mathrm{wt} \%$ the hydrogen production decreases from 1.29 to $0.41 \mathrm{~mol}$ of $\mathrm{H}_{2} / \mathrm{mol}$ of glycerol and gasification efficiency decreases from 52.4658 to 26. $7958 \%$.

For hydrogen production, the remaining significant parameters having a positive effect on hydrogen production can be classified as follows: Temperature $>$ presence of catalyst $(\mathrm{KOH})>$ residence time.

The residence time has a positive effect on $\mathrm{H}_{2}$ production, with a $\mathrm{P}_{\mathrm{H} 2}$-value $=0.007$ and the interaction between temperature and residence time is the only interaction which has an effect on the production of hydrogen, an increase in temperature and residence time together affects negatively the production of hydrogen. So, in the case of high temperatures, it is not necessary to take a long residence time [34].

\section{B. Optimisation}

First, we illustrate the surface plots and contours for the $\mathrm{H}_{2}$ production in terms of the most important factors affecting them as presented in fig. 1 to 4 .

Fig. 1 is the three-dimensional graphical representation of the surface area of the hydrogen produced which shows the effect of the temperature and the initial concentration of glycerol, when the residence time is at 65 minutes, the pressure is held at $25 \mathrm{MPa}$, the catalyst at $1.038 \mathrm{wt} \%$. The graph indicates that the decomposition of glycerol into supercritical water is an overall endothermic process as there is a general trend that as the temperature increases, hydrogen production and gasification efficiency has increased.

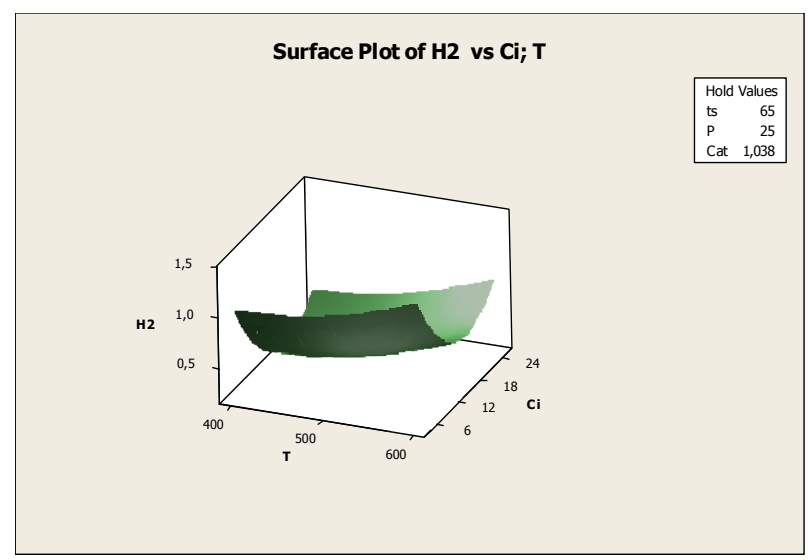

Fig. 1. Surface plot of $\mathrm{H}_{2}$ yield

More detailed information about the effect of glycerol initial concentration and temperature on the hydrogen production, are in the contour plot. Fig. 2 allows to determine approximately the best combination of operating parameters allowing a maximum of hydrogen produced. The graph shows when a residence time is equal to 40 minutes, a pressure of 23 $\mathrm{MPa}$ and $0.6 \mathrm{wt} \%$ of $\mathrm{KOH}$, the temperature is greater than 570 ${ }^{\circ} \mathrm{C}$, allow a maximum hydrogen production higher than 1.4 mol of $\mathrm{H}_{2} / \mathrm{mol}$ of glycerol, using an initial concentration of less than $5 \mathrm{wt} \%$.

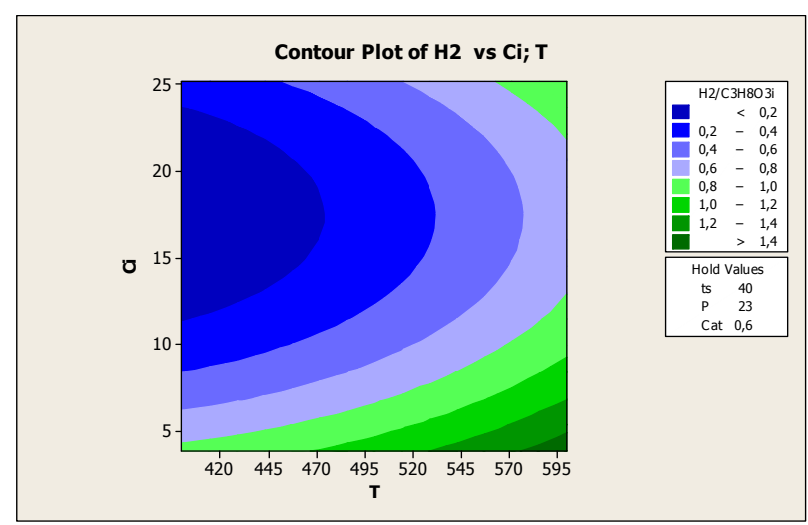

Fig. 2. Contour plot for $\mathrm{H}_{2}$ production (residence time $=40 \mathrm{~min}$, Pressure $=$ $23 \mathrm{MPa}, 0,6 \mathrm{wt} \%$ of $\mathrm{KOH}$ as catalyst). 
Then, the optimizer of Minitab was used to obtain the exact optimal operating conditions for a maximum desired response. Figure 5 enables a comparison of the two cases: operating conditions obtained from the optimization of the hydrogen yield.

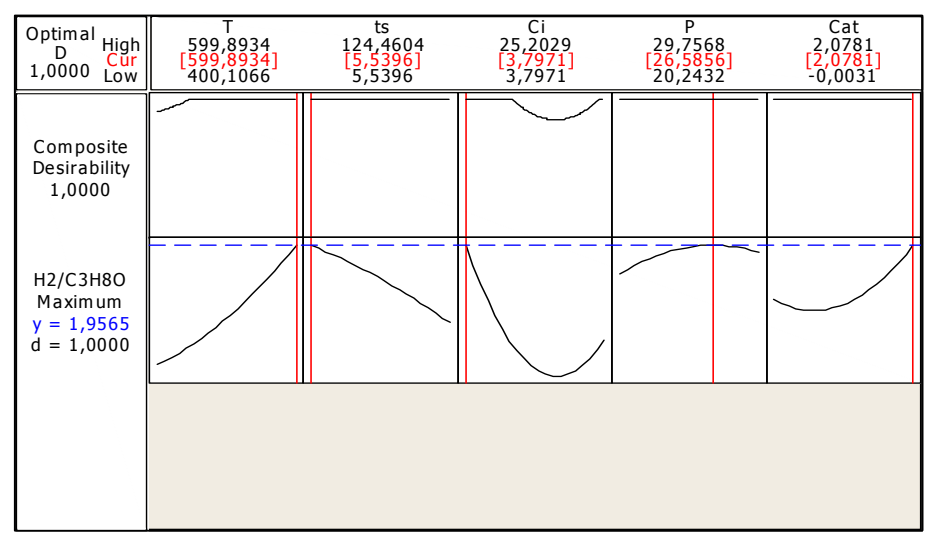

Fig. 3. Minitab results from the optimizer for the hydrogen production.

The optimum factors for the maximum hydrogen yield are presented in Table III, $3.7971 \mathrm{wt} \%$ of glycerol concentration and $2.0781 \mathrm{wt} \%$ of $\mathrm{KOH}$ catalyst, make it possible to obtain $1.9565 \mathrm{~mol}$ of hydrogen / mol of glycerol, at optimal conditions of a temperature of $599.8934^{\circ} \mathrm{C}$, a residence time of 5.5396 minutes and a pressure of $26.5856 \mathrm{MPa}$.

TABLEIV.OPTIMAL CONDITIONS AND CORRESPONDING OPTIMAL RESPONSES FOR A MAXIMUM OF HYDROGEN PRODUCTION.

\begin{tabular}{|c|c|c|c|c|c|}
\hline \multicolumn{5}{|c|}{ Optimal conditions } \\
\hline $\begin{array}{c}\text { Valu } \\
\text { es }\end{array}$ & $\begin{array}{c}\text { Temperatur } \\
\text { e }\end{array}$ & $\begin{array}{c}\text { Residenc } \\
\text { e time }\end{array}$ & $\begin{array}{c}\text { Initial } \\
\text { concentratio } \\
\text { n of glycerol }\end{array}$ & $\begin{array}{c}\text { Pressur } \\
\text { e }\end{array}$ & $\begin{array}{c}\text { Presence of } \\
\text { catalyst(KO } \\
\text { H) }\end{array}$ \\
\hline Real & $\begin{array}{c}599.8934^{\circ} \\
\mathrm{C}\end{array}$ & $\begin{array}{c}5.5396 \\
\text { minutes }\end{array}$ & $3.79 \mathrm{wt} \%$ & $\begin{array}{c}26.585 \\
6 \mathrm{MPa}\end{array}$ & $2.0781 \mathrm{wt} \%$ \\
\hline \multicolumn{7}{|c|}{$\mathbf{H}_{2}(\mathrm{~mol}$ of hydrogen / mol of glycerol) } \\
\hline \multicolumn{5}{|c|}{1.9565} \\
\hline
\end{tabular}

TABLEV. OPTIMAL CONDITIONS AND CORRESPONDING OPTIMAL RESPONSES FOR A MAXIMUM OF GASIFICATION EFFICIENCY AND HYDROGEN PRODUCTION.

\begin{tabular}{|c|c|c|c|c|c|}
\hline \multicolumn{5}{|c|}{ Optimal conditions } \\
\hline Values & Temperature & $\begin{array}{c}\text { Residence } \\
\text { time }\end{array}$ & $\begin{array}{c}\text { Initial } \\
\text { concentration } \\
\text { of glycerol }\end{array}$ & Pressure & $\begin{array}{c}\text { Presence of } \\
\text { catalyst(KOH) }\end{array}$ \\
\hline Real & $599.8934^{\circ} \mathrm{C}$ & $\begin{array}{c}60.7957 \\
\text { minutes }\end{array}$ & $3.79 \mathrm{wt} \%$ & $21.3 \mathrm{MPa}$ & $0.102 \mathrm{wt} \%$ \\
\hline \multicolumn{7}{|c|}{ Optimal responses } \\
\hline
\end{tabular}

The composition of the produced syngas changes according to the operating conditions of the reaction. For the optimized conditions, fig. 7 presents the detailed composition of the synthesis gas obtained with the optimal conditions allowing a maximum production of hydrogen only, and a maximum of hydrogen yield and gasification efficiency, respectively.

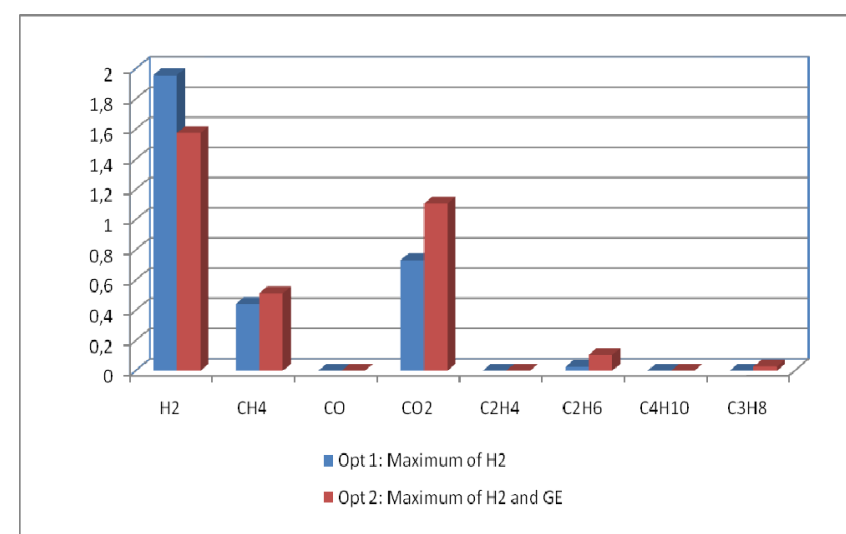

Fig. 4. Composition of the synthesis gas mixture product obtained according to the objective of optimization.

\section{CONCLUSION}

In this research, the supercritical water gasification of pure glycerol was studied in the presence of alkaline catalyst $(\mathrm{KOH})$ in mini autoclaves, using the surface response methodology (RSM) and the central composite design (CCD), this allowed to obtain a mathematical model of the second degree describing the production of hydrogen and gasification efficiency according to five operating parameters: temperature, residence time, initial glycerol concentration, pressure and presence of catalyst $(\mathrm{KOH})$, and to study the effect of these parameters on the response studied. The significance tests showed that the initial concentration of glycerol had the most significant negative effect, while the pressure had no significant effect. However, temperature and residence time have a positive effect, and the presence of catalyst has a positive effect on hydrogen production. The interaction between temperature and residence time has a negative effect on the production of hydrogen, this is explained by the fact that a long residence time is not necessary when handling at high temperatures.

The operating conditions obtained for an optimization aimed at a maximum of hydrogen produced of $1.95 \mathrm{~mol}$ of $\mathrm{H}_{2}$ / mol of glycerol, are of temperature $=599.8934^{\circ} \mathrm{C}$, residence time $=5.5396 \mathrm{~min}$, a pressure of $26.5856 \mathrm{MPa}$ for an initial glycerol concentration of $3.7971 \mathrm{wt} \%$ and in the presence of 2 wt $\%$ of $\mathrm{KOH}$.

\section{REFERENCES}

[1] Douette AMD, Turn SQ, Wang W, Keffer VI. "Experimental investigation of hydrogen production from glycerin reforming”. Energy \& Fuels, Vol. 21(6), pp.3499-3504, 2007. 
[2] A. Bahadar, M. Bilal Khan. "Progress in energy from microalgae: A review. Renewable and Sustainable Energy Reviews".Vol. 27, pp.128148, 2013.

[3] Levin, D. B.; Pitt, L.; Love, M. "Biohydrogen production: Prospects and limitations to practical application.” International Journal of Hydrogen Energy. Vol. 29 (2),pp.173-185, 2004.

[4] K. Nath, D. Das.” Hydrogen from biomass. Current Science”.vol. 85 (3), pp. 265-271, 2003.

[5] Turner J, Sverdrup G,Mann MK, Maness PC, Kroposki B, Ghirardi M, Evans RJ, Blake D. "Renewable hydrogen production". International Journal of Energy Research. Vol. 32, pp. 379-407, 2008.

[6] B. Yan, J. Wu, C. Xie, F. He, C. Wei. "Supercritical water gasification with $\mathrm{Ni} / \mathrm{ZrO} 2$ catalyst for hydrogen production from model wastewater of polyethylene glycol”. Journal of Supercritical Fluids. Vol. 50, pp.155$161,2009$.

[7] L.J. Guo, Y.J. Lu, X.M. Zhang, C.M. Ji, Y. Guan, A.X. Pei. "Hydrogen production by biomass gasification in supercritical water: A systematic experimental and analytical study." Catalysis today. vol129, pp.275286, 2007.

[8] D. Ballerini. «Les biocarburants: répondre aux défis énergétiques et environnementaux des transports ». Editions Technip. 2011.

[9] MOLETTA René. » Le traitement des déchets ». Editions Tec\&Doc Lavoisier. 2009.

[10] A.Kumar, D. Jones, M. Hanna. "Thermochemical biomass gasification: A review of the current status of the technology". Energies. vol . 2 (3), pp.556-581, 2009.

[11] Ruiz JC, Boutin O. « Gazeification de biomasse en eau supercritique ». Edition Technique de l'ingenieur.. Saint Denis. France. 2013.

[12]M. Ni, D.Y.C. Leung, M.K.H. Leung, K.Sumathy, "An overview of hydrogen production from biomass", Fuel Process Technol. Vol. 87, pp.461-472, 2006.

[13] L. Zhang, C.C. Xu, P. Champagne. "Overview of recent advances in thermo-chemical conversion of biomass". Energy Conversion Management. Vol. 51, pp.969-982, 2010.

[14] D.Elif, A. Nezihe. " Hydrogen production by supercritical water gasification of fruit pulp in the presence of $\mathrm{Ru} / \mathrm{C}$ ", International Journal of Hydrogen Energy. Vol. 41 (19), pp.8073-8083, 2016.

[15] S.Nanda, S.N. Reddy, Dai-Viet N. Vo, Bichitra N. Sahoo, J.A. Kozinski. "Catalytic gasification of wheat straw in hot compressed (subcritical and supercritical) water for hydrogen production". Energy Science \&Engineering. Vol. 6(5): 448- 459, 2018.

[16] Ebrahimi-Nik, Mohammadali, M. Almassi, M. Javad Sheikhdavoodi, A.Kruse, H.Bahrami. "Gasification of sugarcane bagasse in supercritical water: effect of pressure and reaction time". The 9 th International Energy conference.

[17] E.Kıpçak, Onur O. Sogut, M.Akgun. "Hydrothermal gasification of olive mill wastewater as a biomass source in supercritical water". The Journal of supercritical fluids. Vol. 57 (1), pp.50-57, 2011.

[18]: X.H. Hao, L.J. Guo, X. Mao, X.M. Zhang, X.J. Chen. "Hydrogen production from glucose used as a model compound of biomass gasified in supercritical water". International Journal of Hydrogen Energy. Vol 28(1), pp.55-64. 2003.

[19]: F.L. P. Resende, S. A. Fraley, M. J. Berger and P.E. Savage. "Noncatalytic gasification of lignin in Supercritical Water". Energy Fuels, vol. 29 (3), 1776-1784, 2015
[20]: B.F. Tapah, R.C.D. Santos, G.A. Leeke. "Processing of glycerol under sub and supercritical water conditions". Renewable Energy. Vol. 62: 353-361, 2014.

[21]: Y. J. Lu, H. Jin, L. J. Guo, X. M. Zhang, C. Q. Cao, and X. Guo "Hydrogen production by biomass gasification in supercritical water with a fluidized bed reactor". International Journal of Hydrogen Energy. Vol. 33(21), pp. 6066-6075, 2008

[22] Wu M. Study of process of conversion of biomass to supercritical water to obtain hydrogen. Application to glucose, glycerol and bio-glycerol. Etude de procedes de conversion de biomasse en eau supercritique pour l'obtention d'hydrogène. Application au glucose, glycerol et bioglycerol.. French: Universite de Toulouse. Unite de recherche RAPSODEE; Toulouse France, 2012.

[23] A.J. Byrd, K.K. Pant , Ram B. Gupt. "Hydrogen production from glycerol by reforming in supercritical water over $\mathrm{Ru} / \mathrm{Al}_{2} \mathrm{O}_{3}$ catalyst". Fuel. Vol. 87 (13-14), pp. 2956-2960, 2008.

[24] S. Guo, L. Guo, C. Cao, J. Yin, Y. Lu, X.Zhang. "Hydrogen production from glycerol by supercritical water gasification in a continuous flow tubular reactor". International Journal of Hydrogen Energy. Vol. 37(7), pp.5559-5568, 2012.

[25]: Z.Ge, H. Jin. L. Guo. "Hydrogen production by catalytic gasification of coal in supercritical water with alkaline catalysts: Explore the way to complete gasification of coal". International Journal of Hydrogen Energy. Vol. 39(34), pp. 19583-19592, 2014.

[26] K.Kang, R. Azargohar, Ajay K. Dalai and H. Wang. "Noncatalytic Gasification of Lignin in Supercritical Water Using a Batch Reactor for Hydrogen Production: An Experimental and Modeling Study". Energy \& Fuels. Vol. 29(3), pp.1776-1784, 2015.

[27] Abdul Raheem, Guozhao Ji, Asif Memon, Siva Sivasangar, Wei Wang, Ming Zhao,Yun Hin, Taufiq-Yap. "Catalytic gasification of algal biomass for hydrogen-rich gas production: Parametric optimization via central composite design". Energy Conversion and Management. vol $158,2017$.

[28] R. N. Reddy, S. S. Patel, Sai Kumar Nair and Y.V.N.S. Suvikram, "Preparation of Hydrogen from Glycerol via Steam Reforming Process", INSTITUTE OF TECHNOLOGY, NIRMA UNIVERSITY, AHMEDABAD - 382 481, 08-10 DECEMBER, 2011.

[29] Pagliaro M, Ciriminna R, Kimura H, Rossi M, Della Pina C. "From Glycerol to Value-Added Products. Angew ». Chemical International Edition. Vol.46, pp.4434-4440, 2007.

[30] F.Yang, M.A. Hanna, David B. Marx and Runcang Sun. "Optimization of hydrogen production from supercritical water gasification of crude glycerol-byproduct of biodiesel production". International Journal of Energy Research. Vol.37(13), 2013.

[31] Q. M. Yu-Wu , E. Weiss-Hortala, R. Barna , H. Boucard \& S. Bulza. "Glycerol and bioglycerol conversion in supercritical water for hydrogen production". Environmental Technology. Vol. 33(19), pp. 2245-2255, 2012.

[32] G. W. Huber, J. W. Shabaker and J. A. Dumesic. "Raney Ni-Sn Catalyst for H2 Production from Biomass-Derived Hydrocarbons". Science. Vol. 300, pp. 2075-2078, 2003.

[33] M. Watanabe, H. Inomata, M.Osada, T.Sato, T. Adschiri, K. Arai. "Catalytic effects of $\mathrm{NaOH}$ and $\mathrm{ZrO} 2$ for partial oxidative gasification of n-hexadecane and lignin in supercritical water". Fuel. Vol. 82(5), pp. 545-552, 2003.

[34] Y. J. Lu, L. J. Guo, C. M. Ji, X. M. Zhang, X. H. Hao and Q. H. Yan, "Hydrogen production by biomass gasification in supercritical water: A parametric study." Int J Hydrogen Energy, vol. 31, pp. 822-831, 2006. 